\title{
Effect of dietary physically effective fiber on ruminal fermentation and the fatty acid profile of milk in dairy goats
}

\author{
Fei $\mathrm{Li},{ }^{*}$ Zongjun $\mathrm{Li},{ }^{*}$ Shengxiang $\mathrm{Li},{ }^{*}$ James $\mathrm{D}$. Ferguson, $\dagger$ Yangchun Cao, ${ }^{\star}$ Junhu Yao, ${ }^{* 1}$ Feifei Sun, ${ }^{*}$ \\ Xiao Wang, ${ }^{*}$ and Ting Yang ${ }^{\star}$ \\ ${ }^{*}$ College of Animal Science and Technology, Northwest A\&F University, Yangling, Shaanxi 712100, China \\ †University of Pennsylvania, School of Veterinary Medicine, Kennett Square 19348
}

\begin{abstract}
The objective of this experiment was to characterize the relationship among rumen fermentation variables, milk fatty acid profile, and dietary physically effective neutral detergent fiber (peNDF) content in a study that controlled for the potential confounding effects of dissimilar dry matter intake among treatments. Ten multiparous Xinong Saanen dairy goats were divided into 2 groups with 2 ruminally cannulated goats per group. Goats in each group were assigned to 1 of 2 dietary treatments (high and low peNDF) according to a $2 \times 2$ crossover design with 2 periods. The peNDF content of alfalfa hay (proportion of neutral detergent fiber retained on an $8.0-\mathrm{mm}$ screen) was $42.1 \%$ for the high-peNDF and $14.5 \%$ for the low-peNDF group. To ensure similar dry matter intake, each morning the amount of alfalfa hay consumed on the prior day by the high-peNDF group was determined (amount offered minus morning refusals), and this was the amount of hay offered to the low-peNDF group that day. Each adaptation period consisted of $21 \mathrm{~d}$, followed by a $9-\mathrm{d}$ sampling period. Dry matter intake and milk production and composition were similar between treatments. Milk energy efficiency increased with low dietary peNDF. Duration of $\mathrm{pH}$ below 5.60 was longer for goats fed the low-peNDF ration compared with the high-peNDF ration (4.08 vs. $0.41 \mathrm{~h} / \mathrm{d})$; however, mean rumen $\mathrm{pH}$ (6.05 vs. 6.13) was not different between treatments. Reducing dietary peNDF increased rumen total volatile fatty acids (114.6 vs. $95.1 \mathrm{mM}$ ) and decreased chewing time (404 vs. $673 \mathrm{~min} / \mathrm{d}$ ), but did not affect the ratios of acetate, propionate, and butyrate. The relative abundance of Fibrobacter succinogenes and Ruminococcus flavefaciens increased with reduced dietary peNDF, but Ruminococcus albus proportions were not influenced by treatment. Reducing dietary peNDF decreased the proportion of iso C14:0, iso C15:0, and trans-11 C18:1
\end{abstract}

Received April 3, 2013.

Accepted January 2, 2014.

${ }^{1}$ Corresponding author: yaojunhu2004@sohu.com in milk fat, whereas the iso C17:0 and trans-10 C18:1 increased. This study demonstrated that low dietary peNDF in dairy goats increases rumen volatile fatty acids, reduces chewing time, and is correlated to the amount of $F$. succinogenes and $R$. flavefaciens.

Key words: physically effective neutral detergent fiber, rumen fermentation, subacute ruminal acidosis, dairy goat

\section{INTRODUCTION}

In the dairy industry, diets are formulated for high energy to meet the requirements of animals and encourage maximal milk production (Beauchemin and Yang, 2005; Zebeli et al., 2008). Subacute ruminal acidosis is a common metabolic disorder in intensive dairy production system and affects rumen function, productivity, and animal health (Zebeli et al., 2008). Subacute ruminal acidosis can be triggered by high amounts of rapidly fermentable carbohydrates and insufficient physically effective NDF (peNDF) in diets (Plaizier et al., 2008). It is commonly believed that dietary forage particle size regulates rumen $\mathrm{pH}$ by affecting chewing and saliva production (Mertens, 1997).

Dry matter intake is sensitive to dietary peNDF; as peNDF decreases, passage rate and DMI increases (Teimouri Yansari et al., 2004; Zebeli et al., 2008). Conversely, excessive peNDF may reduce voluntary feed intake because of the physical limitations of rumen fill (Allen, 2000; Zebeli et al., 2010). Zhao et al. (2011) found that DMI linearly decreased (1.09 to 0.93 $\mathrm{kg} / \mathrm{d}$ ) with increasing dietary peNDF ${ }_{8.0}$ content (2.2 to $13.1 \% \mathrm{DM}$ ) in dairy goats. Because DMI increases with decreasing dietary peNDF in a certain range $\left(\mathrm{peNDF}_{8.0}\right.$ $>14.9 \%$; Zebeli et al., 2010), changes of ruminal $\mathrm{pH}$ due to peNDF are often confounded with different intakes of fermentable OM, which affects the production of VFA in rumen. Therefore, studies have yet to determine whether the reduced ruminal $\mathrm{pH}$ observed when a low-peNDF diet is fed is the result of reduced buffer capacity because of a decrease in chewing time or an increase in fermentable carbohydrate intake. 
A recent study indicated that the odd- and branchedchain FA (OBCFA) of milk fat can be used as a biomarker to detect SARA (Fievez et al., 2012). These FA are originated from rumen microflora and are sensitive to high-grain or low-peNDF diet-induced SARA (Khafipour et al., 2009b). Although studies have evaluated the relationship between rumen $\mathrm{pH}$ and milk OBCFA in grain-based SARA (Vlaeminck et al., 2006b; Alzahal et al., 2010), information regarding dietary peNDFbased SARA remains limited. The objectives of the present experiment were to (1) characterize the interrelationships among rumen $\mathrm{pH}, \mathrm{VFA}$ concentration, and dietary peNDF content by controlling the confounding effects of dissimilar nutrient intakes and (2) determine the profile of OBCFA in milk in response to dietary peNDF content.

\section{MATERIALS AND METHODS}

\section{Animal, Diet, and Experimental Design}

All experimental procedures were approved by the Northwest A\&F University Animal Care and Use Committee. Ten multiparous (4 with rumen cannulas) Xinong Saanen dairy goats (DIM $=68 \pm 6$; $\mathrm{BW}=$ $54 \pm 3 \mathrm{~kg}$ ) were paired based on BW and milk yield and randomly assigned to 1 of the 2 dietary treatments according to a paired $2 \times 2$ crossover design in 2 study periods. Each experimental period was 30 d, with 21 $\mathrm{d}$ for adaptation to diets and $9 \mathrm{~d}$ for sample collection and measurements. Dietary treatments were prepared by chopping alfalfa hay to a theoretical cut length of $20 \mathrm{~mm}$ (high peNDF) using a forage cutter equipped with 6 knives, or by grinding alfalfa hay through a 4-mm sieve (low peNDF) with a forage grinder (Table 1). Goats were fed equal proportions twice daily, at 0700 and $1900 \mathrm{~h}$, and had free access to fresh water throughout the experiment.

Diets contained (DM basis) $43.7 \%$ alfalfa hay, $5.5 \%$ corn silage, and $50.8 \%$ concentrate (Table 1 ). The concentrate and corn silage were mixed and fed to goats 15 min before feeding alfalfa hay. Each morning, orts of long peNDF were determined and subtracted from the amount of hay provided the previous day to calculate the hay intake of the goat consuming the high-peNDF diet. This amount of hay was offered that day to the low-peNDF paired goat. This process ensured that identical feed intake and forage-to-concentrate ratio were maintained between the pairs of goats in the lowand high-peNDF treatments.

\section{Sample Collection and Measurements}

During collection periods, the amounts of feed offered and residual was recorded daily for each goat. Feed samples were collected daily and pooled for each collection period. Individual goat ort samples were collected daily and pooled by period for each goat to determine the particle distribution of refusals at the end of each period. Alfalfa hay (high or low peNDF), corn silage, and concentrate samples were collected once every $3 \mathrm{~d}$ to determine particle distribution and chemical composition. Particle size distribution of feed was determined by using a Penn State Particle Separator containing 3 sieves $(19,8$, and $1.18 \mathrm{~mm}$ ) and 1 pan (Kononoff et al., 2003). Physical effectiveness factors (pef) for alfalfa hay, corn silage, and concentrate were calculated as the sum of the DM proportion retained on 19 and $8 \mathrm{~mm}$ (pef $_{8.0}$; Lammers et al., 1996) or the 19, 8, and $1.18 \mathrm{~mm}$ (pef $_{1.18}$; Kononoff et al., 2003). By multiplying NDF content of the feed by $\operatorname{pef}_{8.0}$ and pef $_{1.18}$, the peNDF ${ }_{8.0}$ and peNDF$_{1.18}$ content, respectively, of each feed was calculated (Yang and Beauchemin, 2007). Alfalfa hay, corn silage, and concentrate, as well as particles retained on the different sieves, were weighed, dried at $70^{\circ} \mathrm{C}$, and stored for chemical analysis.

Ruminal fluid (approximately $50 \mathrm{~mL}$ ) was collected from the ventral rumen sac at 0700 (before feed delivery), 1000, 1300, and $1600 \mathrm{~h}$ on d 21; 0800, 1100, 1400, and $1700 \mathrm{~h}$ on d 22; and 0090, 1200, 1500, and $1800 \mathrm{~h}$ on d 23. Each sample was squeezed through 4 layers of cheesecloth. For VFA analysis, $4 \mathrm{~mL}$ of filtrate in each sample was mixed with $1 \mathrm{~mL}$ of $25 \%$ (wt/vol) metaphosphoric acid and stored at $-20^{\circ} \mathrm{C}$.

Goats were milked twice daily (0700 and $1800 \mathrm{~h}$ ) and milk production was quantified using an electronic balance $(30,000 \pm 2 \mathrm{~g})$. Milk samples were collected in 8 consecutive milkings (21-24 d) in two 50-mL vials; one portion was used to analyze milk fat, protein, and lactose by using a MilkoScan FT120 (Foss Electric, Hillerød, Denmark). The remaining portion of the sample was stored at $-20^{\circ} \mathrm{C}$ and used to determine the profile of milk FA.

Rumen $\mathrm{pH}$ was continuously monitored from 0700 to $1300 \mathrm{~h}$ on d 24, 1300 to $1900 \mathrm{~h}$ on d 25, 1900 (d 26) to $0100 \mathrm{~h}$ (d 27), and 0100 to $0700 \mathrm{~h}$ on d 28 in each cannulated goat. The $\mathrm{pH}$ was measured using an industrial electrode linked to a $\mathrm{pH}$ transmitter and a data logger was used to record data as described in detail by Zhao et al. (2011). Ruminal pH data were collected every $5 \mathrm{~s}$ and averaged every 5 min. Ruminal pH data were summarized across $24 \mathrm{~h}$ for each goat as mean, area, and time under $\mathrm{pH} 5.80$ or 5.60 . The area was calculated by adding the absolute value of negative deviations in $\mathrm{pH}$ from 5.6 or 5.8 for each 5 -min interval.

The chewing activity of each goat was continuously monitored for $24 \mathrm{~h}$ from d $29(0700 \mathrm{~h})$ to $30(0700 \mathrm{~h})$ in each period (Krause and Combs., 2003). Eating and ruminating activities were observed every $5 \mathrm{~min}$ and 
Table 1. Ingredients and chemical composition of the alfalfa hay (long and fine) and experimental diets [high or low physically effective NDF (peNDF)]

\begin{tabular}{|c|c|c|c|c|}
\hline \multirow[b]{2}{*}{ Item } & \multicolumn{2}{|c|}{ Treatment diet } & \multicolumn{2}{|c|}{ Alfalfa hay } \\
\hline & High peNDF & Low peNDF & Long & Short \\
\hline \multicolumn{5}{|l|}{ Ingredient, \% DM } \\
\hline Alfalfa hay, long & 43.7 & - & & \\
\hline Alfalfa hay, short & - & 43.7 & & \\
\hline Corn silage & 5.5 & 5.5 & & \\
\hline Corn & 38.6 & 38.6 & & \\
\hline Soybean meal & 8.0 & 8.0 & & \\
\hline Wheat bran & 1.9 & 1.9 & & \\
\hline Vitamin-mineral premix ${ }^{1}$ & 1.0 & 1.0 & & \\
\hline Dicalcium phosphate & 0.4 & 0.4 & & \\
\hline Salt & 0.9 & 0.9 & & \\
\hline \multicolumn{5}{|l|}{ Chemical composition } \\
\hline DM, $\%$ & 84.1 & 84.2 & 86.1 & 86.4 \\
\hline OM, \% DM & 92.3 & 92.5 & 90.6 & 90.5 \\
\hline $\mathrm{CP}, \% \mathrm{DM}$ & 13.4 & 13.6 & 15.6 & 15.6 \\
\hline NFC, $\%$ DM & 44.4 & 44.9 & 20.5 & 21.1 \\
\hline $\mathrm{NDF}, \% \mathrm{DM}$ & 34.7 & 34.2 & 55.1 & 54.8 \\
\hline $\mathrm{ADF}, \% \mathrm{DM}$ & 21.3 & 21.0 & 40.1 & 40.0 \\
\hline Forage NDF, \% DM & 27.4 & 27.7 & & \\
\hline \multicolumn{5}{|c|}{ Particle composition, \% DM retained on sieve ${ }^{2}$} \\
\hline $19.0 \mathrm{~mm}$ & 17.8 & 3.5 & 30.2 & 1.1 \\
\hline $8.0 \mathrm{~mm}$ & 39.7 & 21.1 & 46.3 & 25.2 \\
\hline $1.18 \mathrm{~mm}$ & 11.5 & 30.1 & 14.8 & 41.7 \\
\hline pan & 31.0 & 45.3 & 8.7 & 32.0 \\
\hline $\operatorname{pef}_{8.0}$ & 0.58 & 0.25 & 0.77 & 0.26 \\
\hline pef $_{1.18}$ & 0.69 & 0.55 & 0.91 & 0.68 \\
\hline peNDF $_{8.0}$ & 20.5 & 8.4 & 42.1 & 14.5 \\
\hline $\operatorname{peNDF}_{1.18}$ & 24.3 & 18.7 & 50.3 & 37.4 \\
\hline
\end{tabular}

${ }^{1}$ Vitamin-mineral mix (per kilogram): $450 \mathrm{mg}$ of nicotinic acid, $600 \mathrm{mg}$ of Mn, $950 \mathrm{mg}$ of Zn, $430 \mathrm{mg}$ of Fe, 650 $\mathrm{mg}$ of $\mathrm{Cu}, 30 \mathrm{mg}$ of $\mathrm{Se}, 45 \mathrm{mg}$ of I, $20 \mathrm{mg}$ of $\mathrm{Co}, 800 \mathrm{mg}$ of vitamin E, 45,000 IU of vitamin D, and 120,000 IU of vitamin A.

${ }^{2}$ peNDF $_{8.0}$ and peNDF $_{1.18}=$ physically effective NDF determined as the NDF content of a mixed diet multiplied

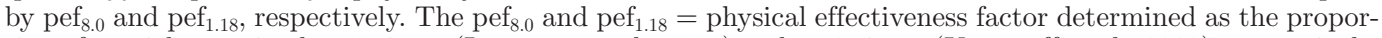
tion of particles retained on 2 sieves (Lammers et al., 1996) and on 3 sieves (Kononoff et al., 2003), respectively.

each activity was assumed to last 5 min. Total chewing time was calculated as the sum of eating and ruminating time. To determine rumen bacterial counts, rumen contents were obtained from goats twice daily at 0700 and $1900 \mathrm{~h}$ on $\mathrm{d} 22$ and 25 before the morning and evening feedings and stored at $-80^{\circ} \mathrm{C}$ before extracting genomic DNA.

\section{Chemical Analyses}

Dry matter content of samples was determined by drying at $135^{\circ} \mathrm{C}$ for $3 \mathrm{~h}$ (AOAC, 1990). Ash content was determined by combustion at $550^{\circ} \mathrm{C}$ for $6 \mathrm{~h}$, and $\mathrm{OM}$ was calculated as the difference between DM and ash. The NDF and ADF contents were sequentially determined according to methods described by Van Soest et al. (1991) with a heat stable $\alpha$-amylase (A3306, Sigma-Aldrich, St. Louis, MO) and sodium sulfite used in the NDF procedure (inclusive of residual ash). Crude protein content was determined by Kjeldahl procedure (AOAC, 1990).
Milk fat was extracted according to the rapid method proposed by Luna et al. (2005). Thirty grams of raw milk were centrifuged at $17,800 \times g$ at $20^{\circ} \mathrm{C}$ for 30 $\mathrm{min}$. The fat layer was removed, transferred to a $2-\mathrm{mL}$ microtube and centrifuged at $19,300 \times g$ at $20^{\circ} \mathrm{C}$ for 20 min. Methyl esters of extracted fat were prepared by base catalyzed methanolysis of the glycerides using $\mathrm{KOH}$ in methanol as described in ISO-IDF (2002).

Fatty acid methyl esters of milk samples were analyzed by the Agilent 7820 A GC system equipped with a flame ionization detector at $250^{\circ} \mathrm{C}$, and an SP 2560 fused silica capillary column $(100 \mathrm{~m} \times 0.25 \mathrm{~mm} \times 0.20$ $\mu \mathrm{m}$ film thickness; Supelco, Bellefonte, PA). Nitrogen was used as the carrier gas at a constant flow rate of $1 \mathrm{~mL} / \mathrm{min}$ and the injection volume was $1 \mu \mathrm{L}$. The column temperature was held at $70^{\circ} \mathrm{C}$ for 2 min after injection, increased at $20^{\circ} \mathrm{C} / \mathrm{min}$ to $175^{\circ} \mathrm{C}$ and held for $25 \mathrm{~min}$, then increased at $2.5^{\circ} \mathrm{C} / \mathrm{min}$ to $230^{\circ} \mathrm{C}$ and held for $18 \mathrm{~min}$. For C18:1 isomers, the temperature program was adopted from Vlaeminck et al. (2005), that is, held at $150^{\circ} \mathrm{C}$ for $2 \mathrm{~min}$, increased to $158^{\circ} \mathrm{C}$ at $1^{\circ} \mathrm{C} /$ 
Table 2. Polymerase chain reaction primers for amplifying target populations

\begin{tabular}{lll}
\hline Target species $^{1}$ & Forward primer & Reverse primer \\
\hline General bacteria & CGGCAACGAGCGCAACCC & CCATTGTAGCACGTGTGTAGCC \\
Fibrobacter succinogenes & GTTCGGAATTACTGGGCGTAAA & CGCCTGCCCCTGAACTATC \\
Ruminococcus flavefaciens & CGAACGGAGATAATTTGAGTTTACTTAGG & CGGTCTCTGTATGTTATGAGGTATTACC \\
Ruminococcus albus & CCCTAAAAGCAGTCTAGTTCG & CCTCCTTGCGGTTAGAACA \\
Streptococcus bovis & TTCCTAGAGATAGGAAGTTTCTTCGG & ATGATGGCAACTAACAATAGGGGT \\
\hline
\end{tabular}

${ }^{1}$ Primers of general bacteria, Fibrobacter succinogenes, and Ruminococcus flavefaciens referred to McSweeney and Denman (2007); Ruminococcus albus referred to Wang et al. (1997); Streptococcus bovis referred to Stevenson and Weimer (2007).

min and held for $28 \mathrm{~min}$, then increased at $1^{\circ} \mathrm{C} / \mathrm{min}$ to $196^{\circ} \mathrm{C}$. Standard FA methyl esters were $47885-\mathrm{U}(37$ FAME, Supelco), 546B (Nu-Chek Prep Inc., Elysian, $\mathrm{MN}$ ), and OBCFA (BR2, BR3, ME93; Larodan Fine Chemicals, Malmö, Sweden) were used to identify and quantify the FA profiles in samples.

Thawed rumen fluid samples were centrifuged for 15 min at $19,000 \times g$ at $4^{\circ} \mathrm{C}$. A 2 -mL supernatant was mixed with $200 \mu \mathrm{L}$ of crotonic acid (1\%, wt/vol) and then filtered through a $0.45-\mu \mathrm{m}$ filter. Concentrations of ruminal VFA were separated and quantified by gas chromatography (Agilent Technologies 7820 GC system) using a $30 \mathrm{~m} \times 0.25 \mathrm{~mm} \times 0.33 \mu \mathrm{m}$ fused silica column (AE-FFAP; Atech Technologies Co. Ltd., Taipei, Taiwan, China). The injector and detector temperatures were set at 200 and $250^{\circ} \mathrm{C}$, respectively. The column temperature was increased from 45 to $150^{\circ} \mathrm{C}$ at $20^{\circ} \mathrm{C} / \mathrm{min}$ and was held for $5 \mathrm{~min}$.

Rumen content samples $(\mathrm{n}=16)$ were thawed and mixed, and 200-mg samples were used to extract total microbial genomic DNA by using a E.Z.N.A. Stool DNA Kit (Omega Bio-Tek, Norcross, GA) following the manufacturer's instructions, which included a bead-beating step for the mechanical lyses of microbial cells. Concentration and purity were both determined by gel electrophoresis and spectrophotometrically using the $\mathrm{A}_{260} / \mathrm{A}_{280}$ (NanDrop 2000, Thermo Scientific Inc., Waltham, MA). The DNA samples were used as templates for quantitative real-time PCR amplification.

The PCR primers used are listed in Table 2. Realtime PCR assays were performed on a Bio-Rad iQ5 multicolor Real-Time PCR Detection System (Bio-Rad Laboratories, Hercules, CA) programmed at $95^{\circ} \mathrm{C}$ for 30 $\mathrm{s}$ for initial denaturation, 40 cycles of $95^{\circ} \mathrm{C}$ for $5 \mathrm{~s}$, and $60^{\circ} \mathrm{C}$ for $30 \mathrm{~s}$ for primer annealing and product elongation. Fluorescence detection was performed at the end of each denaturation and extension step. Amplicon specificity was performed via dissociation curve analysis of PCR end products by raising the temperature at the rate of $1^{\circ} \mathrm{C}$ per $30 \mathrm{~s}$ from 60 to $95^{\circ} \mathrm{C}$. A $25-\mu \mathrm{L}$ PCR mixture was prepared using $12.5 \mu \mathrm{L}$ of SYBR Premix Ex TaqI (Perfect Real Time, Takara Biotechnology, Dalian, China), $1 \mu \mathrm{L}$ of forward primer $(10 \mu M), 1 \mu \mathrm{L}$ of reverse primer $(10 \mu M), 1 \mu \mathrm{L}$ of DNA, and $9.5 \mu \mathrm{L}$ of double-distilled water. The population sizes of specific bacterial groups were expressed as a percentage relative to the abundance of general bacterial $16 \mathrm{~S}$ rRNA gene (reference gene; Denman and McSweeney, 2005).

\section{Calculation and Statistical Analysis}

The milk energy efficiency (MEE) was defined as the ratios between milk energy and DMI (Aguerre et al., 2011). Statistical analysis was conducted on DMI, milk yield, milk compositions, ruminal bacteria abundance, and fermentation parameters. The MIXED procedure (SAS Institute, 2003) was followed using the model $\mathrm{Y}_{i j k l}=\mu+\mathrm{S}_{i}+\mathrm{C}_{j}(\mathrm{~S})_{i}+\mathrm{P}_{k}+\mathrm{T}_{l}+e_{i j k l}$, where $\mathrm{Y}_{i j k l}=$ the dependent variable; $\mu=$ the overall mean; $\mathrm{S}_{i}=$ the effect of diet sequence $i ; \mathrm{C}_{j}(\mathrm{~S})_{i}=$ the random effect of goat $j$ nested within diet $i$ sequence; $\mathrm{P}_{k}=$ the effect of period $k ; \mathrm{T}_{l}=$ the treatment effect; and $e_{i j k l}$ $=$ the random error. Treatment, period, and sequence effect were considered as fixed effects. Sample time was treated as a repeated measure and goat within dietary treatment as subject. Analysis of ruminal $\mathrm{pH}$ and chewing time results were conducted using the same statistical model excluding the sample time effect. Significance was declared at $P \leq 0.05$; tends were discussed at $P<0.10$.

\section{RESULTS}

\section{Particle Size Distribution and peNDF of Alfalfa Hay}

Different particle size variables and peNDF contents were observed in the 2 cut lengths of alfalfa hay (Table 1 ). The proportion of particles retained on the 8- and $19-\mathrm{mm}$ sieves in the low-peNDF group was lower than those in the high-peNDF group and the pef $_{8.0}$ and peNDF $_{8.0}$ were reduced by more than $65 \%$.

\section{DMI, Milk Yield, and Milk Composition}

Data regarding DMI and milk variables are presented in Table 3. Total DMI (1,761 vs. $1,753 \mathrm{~g} / \mathrm{d} ; P=0.85)$ and intake of individual feeds (concentrate, corn silage, and alfalfa) were similar between treatments. Milk 
Table 3. Nutrient intake, milk production, and milk FA of goats fed experimental diets containing shorter or longer chop lengths of alfalfa hay

\begin{tabular}{|c|c|c|c|c|}
\hline Item & High peNDF ${ }^{1}$ & Low peNDF & $\mathrm{SE}$ & $P$-value \\
\hline \multicolumn{5}{|l|}{ Feed intake, $\mathrm{g} / \mathrm{d}$} \\
\hline Concentrate & 880 & 880 & - & - \\
\hline Corn silage intake & 97 & 97 & - & - \\
\hline Alfalfa hay intake & 785 & 774 & 6 & 0.91 \\
\hline NDF intake & 611 & 608 & 7 & 0.84 \\
\hline peNDF $_{8.0}$ intake $^{2}$ & 361 & 147 & 25 & $<0.01$ \\
\hline peNDF $_{1.18}$ intake $^{2}$ & 428 & 327 & 12 & $<0.01$ \\
\hline Total DMI & 1,761 & 1,753 & 19 & 0.85 \\
\hline Milk yield, $\mathrm{g} / \mathrm{d}$ & 2,031 & 2,047 & 36 & 0.91 \\
\hline Fat, $\%$ & 2.63 & 2.84 & 0.18 & 0.53 \\
\hline Protein, \% & 2.88 & 2.86 & 0.08 & 0.92 \\
\hline Lactose, \% & 4.06 & 4.13 & 0.04 & 0.42 \\
\hline Milk energy, ${ }^{3} \mathrm{KJ} / \mathrm{d}$ & 4,780 & 4,998 & 101 & 0.13 \\
\hline $\mathrm{MEE},{ }^{4} \mathrm{KJ} / \mathrm{kg}$ of DMI & 2.71 & 2.85 & 0.03 & 0.04 \\
\hline \multicolumn{5}{|l|}{ Milk FA, \% FA } \\
\hline C11:0 & 0.201 & 0.223 & 0.024 & 0.59 \\
\hline C12:0 & 5.05 & 4.93 & 0.310 & 0.84 \\
\hline $\mathrm{C} 13: 0$ & 0.090 & 0.090 & 0.007 & 0.97 \\
\hline iso $\mathrm{C} 14: 0$ & 0.137 & 0.125 & 0.004 & 0.04 \\
\hline $\mathrm{C} 15: 0$ & 1.002 & 0.978 & 0.018 & 0.46 \\
\hline iso $\mathrm{C} 15: 0$ & 0.321 & 0.234 & 0.018 & 0.03 \\
\hline anteiso $\mathrm{C} 15: 0$ & 0.493 & 0.451 & 0.016 & 0.16 \\
\hline cis-10 C15:1 & 0.067 & 0.062 & 0.017 & 0.41 \\
\hline C16:0 & 26.78 & 28.76 & 0.742 & 0.17 \\
\hline $\mathrm{C} 17: 0$ & 0.733 & 0.677 & 0.024 & 0.14 \\
\hline iso $\mathrm{C} 17: 0$ & 0.377 & 0.487 & 0.024 & 0.05 \\
\hline anteiso $\mathrm{C} 17: 0$ & 0.893 & 0.755 & 0.026 & 0.04 \\
\hline cis-9 C17:1 & 0.327 & 0.296 & 0.014 & 0.34 \\
\hline C18:0 & 8.98 & 7.45 & 0.312 & 0.03 \\
\hline trans-9 C18:1 & 0.424 & 0.527 & 0.043 & 0.18 \\
\hline trans-10 C18:1 & 0.94 & 1.57 & 0.126 & 0.01 \\
\hline trans-11 C18:1 & 4.15 & 2.66 & 0.30 & 0.02 \\
\hline trans-12 C18:1 & 0.273 & 0.259 & 0.028 & 0.75 \\
\hline cis-9 C18:1 & 20.49 & 18.21 & 0.688 & 0.09 \\
\hline cis-11 C18:1 & 0.519 & 0.550 & 0.017 & 0.53 \\
\hline cis-12 C18:1 & 0.254 & 0.219 & 0.275 & 0.31 \\
\hline $\mathrm{C} 18: 2 \mathrm{n}-6$ & 3.04 & 2.78 & 0.132 & 0.29 \\
\hline C18:3n-3 & 0.527 & 0.493 & 0.028 & 0.57 \\
\hline $\mathrm{C} 21: 0$ & 0.286 & 0.273 & 0.064 & 0.73 \\
\hline
\end{tabular}

${ }^{1}$ peNDF $=$ physically effective NDF.

${ }^{2}$ peNDF $_{8.0}$ and peNDF $1.18=$ physically effective NDF determined as the NDF content of a mixed diet multiplied

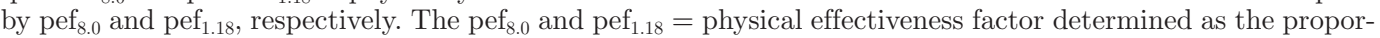
tion of particles retained on 2 sieves (Lammers et al., 1996) and on 3 sieves (Kononoff et al., 2003), respectively.

${ }^{2}$ Milk energy $(\mathrm{KJ} / \mathrm{d})=4.185 \times$ Milk yield $(\mathrm{g} / \mathrm{d}) \times(0.0929 \times$ Fat $\%+0.0547 \times$ Protein $\%+0.0395 \times$ Lactose $\%)$.

${ }^{3} \mathrm{MEE}=$ milk energy efficiency.

yield, milk energy, fat, protein, and lactose concentrations did not differ between treatments. Milk energy efficiency was increased by reducing dietary peNDF (2.71 vs. $2.85 \mathrm{KJ} / \mathrm{kg}$ of DMI; $P=0.04$ ).

\section{Rumen Fermentation and Chewing Activity}

The daily average rumen $\mathrm{pH}$ was not affected by dietary peNDF content (Table 4). Reduced dietary peNDF increased the duration and area of $\mathrm{pH}<5.8$ or $\mathrm{pH}<5.6(P<0.05)$. The total concentration of VFA increased from 95.1 to $114.6 \mathrm{~m} M$ in the low-peNDF group $(P=0.03)$. The molar proportion of individual
VFA and the ratio of acetate to propionate were not affected by treatment $(P>0.05)$. The ruminating and chewing time increased as dietary peNDF level increased $(P<0.05$; Table 4$)$.

\section{Rumen Bacteria and Milk FA}

The relative abundances of ruminal Fibrobacter succinogenes and Ruminococcus flavefaciens were higher (Table 3$)$ in the low- $(P<0.05)$ than in the highpeNDF group. The amount of Ruminococcus albus and Streptococcus bovis were not affected by treatments $(P$ $>0.05)$. 
Table 4. Rumen fermentation, chewing activity, and bacteria abundance for experimental diets [high or low physically effective NDF (peNDF)] containing shorter or longer chop lengths of alfalfa hay

\begin{tabular}{|c|c|c|c|c|}
\hline Item & High peNDF & Low peNDF & $\mathrm{SE}$ & $P$-value \\
\hline \multicolumn{5}{|l|}{$\mathrm{pH}$} \\
\hline Mean & 6.13 & 6.05 & 0.04 & 0.41 \\
\hline Area under $\mathrm{pH} 5.8, \mathrm{pH} \times \mathrm{h} / \mathrm{d}$ & 0.78 & 3.63 & 0.60 & 0.01 \\
\hline Area under $\mathrm{pH} 5.6, \mathrm{pH} \times \mathrm{h} / \mathrm{d}$ & 0.20 & 1.13 & 0.18 & 0.01 \\
\hline $\mathrm{pH}<5.8, \mathrm{~h} / \mathrm{d}$ & 1.65 & 8.55 & 1.12 & 0.03 \\
\hline $\mathrm{pH}<5.6, \mathrm{~h} / \mathrm{d}$ & 0.41 & 4.08 & 0.67 & 0.03 \\
\hline Total VFA, $\mathrm{m} M$ & 95.1 & 114.6 & 4.74 & 0.04 \\
\hline \multicolumn{5}{|l|}{ VFA, mol/100 mol } \\
\hline Acetate $(\mathrm{A})$ & 62.1 & 62.0 & 0.86 & 0.98 \\
\hline Propionate $(\mathrm{P})$ & 21.0 & 20.7 & 0.53 & 0.84 \\
\hline Butyrate & 13.0 & 13.7 & 0.52 & 0.25 \\
\hline Isobutyrate & 1.3 & 1.1 & 0.07 & 0.30 \\
\hline Valerate & 1.0 & 1.0 & 0.05 & 0.51 \\
\hline Isovalerate & 1.6 & 1.4 & 0.10 & 0.27 \\
\hline A:P ratio & 2.97 & 3.00 & 0.21 & 0.92 \\
\hline \multicolumn{5}{|l|}{ Chewing activity } \\
\hline \multicolumn{5}{|l|}{ Eating } \\
\hline $\min / \mathrm{d}$ & 196 & 76 & 14 & $<0.01$ \\
\hline $\mathrm{min} / \mathrm{g}$ of $\mathrm{DM}$ & 0.11 & 0.04 & 0.01 & $<0.01$ \\
\hline $\min / g$ of NDF & 0.32 & 0.12 & 0.02 & 0.011 \\
\hline $\mathrm{min} / \mathrm{g}$ of $\mathrm{peNDF}_{8.0}{ }^{1}$ & 0.55 & 0.51 & 0.02 & 0.36 \\
\hline $\mathrm{min} / \mathrm{g}$ of $\mathrm{peNDF}_{1.18}{ }^{1}$ & 0.46 & 0.23 & 0.03 & $<0.01$ \\
\hline \multicolumn{5}{|l|}{ Ruminating } \\
\hline $\min / \mathrm{d}$ & 478 & 329 & 18 & $<0.01$ \\
\hline $\mathrm{min} / \mathrm{g}$ of $\mathrm{DM}$ & 0.27 & 0.19 & 0.01 & $<0.01$ \\
\hline $\min / \mathrm{g}$ of NDF & 0.78 & 0.54 & 0.03 & $<0.01$ \\
\hline $\mathrm{min} / \mathrm{g}$ of $\mathrm{peNDF}_{8.0}{ }^{1}$ & 1.33 & 2.24 & 0.11 & $<0.01$ \\
\hline $\mathrm{min} / \mathrm{g}$ of $\mathrm{peNDF}_{1.18}{ }^{8}$ & 1.12 & 1.01 & 0.03 & 0.03 \\
\hline \multicolumn{5}{|l|}{ Chewing } \\
\hline $\min / \mathrm{d}$ & 673 & 404 & 32 & $<0.01$ \\
\hline $\min / \mathrm{g}$ of $\mathrm{DM}$ & 0.38 & 0.23 & 0.02 & $<0.01$ \\
\hline $\mathrm{min} / \mathrm{g}$ of $\mathrm{NDF}$ & 1.11 & 0.67 & 0.05 & $<0.01$ \\
\hline $\mathrm{min} / \mathrm{g}$ of $\mathrm{peNDF}_{8.0}{ }^{1}$ & 1.87 & 2.75 & 0.11 & $<0.01$ \\
\hline $\mathrm{min} / \mathrm{g}$ of $\mathrm{peNDF}_{1.18}{ }^{1}$ & 1.58 & 1.24 & 0.05 & $<0.01$ \\
\hline \multicolumn{5}{|l|}{ Bacteria, $\%$ total bacteria } \\
\hline Streptococcus bovis & 0.0026 & 0.0053 & 0.002 & 0.43 \\
\hline Fibrobacter succinogenes & 0.147 & 0.403 & 0.042 & 0.04 \\
\hline Ruminococcus albus & 0.206 & 0.533 & 0.121 & 0.16 \\
\hline Ruminococcus flavefaciens & 0.224 & 0.320 & 0.061 & 0.05 \\
\hline
\end{tabular}

${ }^{1}$ peNDF $_{8.0}$ and peNDF ${ }_{1.18}=$ physically effective NDF determined as the NDF content of a mixed diet multiplied

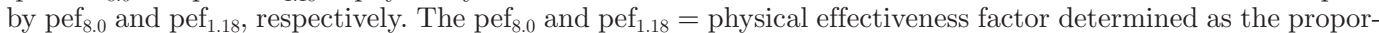
tion of particles retained on 2 sieves (Lammers et al., 1996) and on 3 sieves (Kononoff et al., 2003), respectively.

The FA profile (Table 4) of milk from goats receiving the high-peNDF diet had greater proportions of milk iso $\mathrm{C} 14: 0$, iso $\mathrm{C} 15: 0$, anteiso $\mathrm{C} 17: 0$, trans-10 $\mathrm{C} 18: 1$, and C20:0; however, these goats contained lower proportions of iso $\mathrm{C} 17: 0$ and trans-11 C18:1 than those receiving the low-peNDF $\operatorname{diet}(P<0.05)$. The proportions of other C18:1 isomers, C18:2 n-6 and C18:3 n-3, were not affected by the treatments.

\section{DISCUSSION}

Gozho et al. (2005) defined SARA as when ruminal $\mathrm{pH}$ under 5.6 exceeded $3 \mathrm{~h} / \mathrm{d}$. Subacute ruminal acidosis can reduce growth of ruminal cellulolytic bacteria and cause milk fat depression (MFD) in dairy cows (Krause and Oetzel, 2006). Based on these criteria, we found no evidence that SARA was manifested when goats received the low-peNDF diet, although the time of ruminal $\mathrm{pH}$ below 5.6 was longer than $3 \mathrm{~h} / \mathrm{d}$ in this treatment. The mean ruminal $\mathrm{pH}$ was not affected when the particle size of alfalfa hay was reduced. This result is consistent with previous studies (Kononoff and Heinrichs, 2003; Yang and Beauchemin, 2006; Bhandari et al., 2008). Zebeli et al. (2012) suggested that corn-based concentrate diets had a lower risk of developing SARA than barley-based concentrate diets in ruminants because of the low degradability rate of corn starch. Thus, the corn-based concentrate used in the present study may partly explain the lack of evidence of SARA when goats were fed the low-peNDF diet.

The pair-fed procedure used in the present study was based on the experiment of Wheelock et al. (2010), who 
studied the nutrient distribution of dairy cows under heat stress conditions. This procedure can eliminate the confounding effects of dissimilar nutrient intake among treatments. Zebeli et al. (2008) summarized that DMI decreases slightly as the peNDF ${ }_{1.18}$ content of a ration increases from 21.6 to $31.9 \%$ (DM basis). Studies have also observed that DMI linearly increased (20.1 to 23.4 $\mathrm{kg} / \mathrm{d}$ for dairy cows, and 0.934 to $1.089 \mathrm{~kg} / \mathrm{d}$ for dairy goats) as dietary peNDF ${ }_{1.18}$ decreased (26.7 to $25.7 \%$ and 21.8 to $16.6 \%$, respectively; Kononoff and Heinrichs, 2003; Zhao et al., 2011). If DMI changes as dietary peNDF changes, the effect of peNDF on ruminal $\mathrm{pH}$ and other measurements cannot be isolated from the confounding effect of alteration in fermentable substrate consumed because of the changes in DMI. The current study was able to isolate the effect of reduced chewing activity due to reduction in dietary peNDF while maintaining similar fermentable OM through the control of DMI.

In the current study, the reduced dietary peNDF decreased chewing time and increased ruminal VFA concentration. These results are consistent with data obtained from dairy goats (Zhao et al., 2011). Rumen $\mathrm{pH}$ is determined by the total VFA concentration and buffer capacity of the rumen fluid. In the current study, the low dietary peNDF increased ruminal VFA concentration and decreased chewing activity, which contributed to the increased duration of ruminal $\mathrm{pH}$ below 5.8 and 5.6. Although studies have found that ruminal VFA increased by reducing dietary peNDF (Kononoff and Heinrichs, 2003; Beauchemin and Yang, 2005; Khafipour et al., 2009a), these studies cannot avoid the confounding effect of higher DMI (higher fermentable carbohydrate intake) in the low- compared with the high-peNDF diets.

Several factors, including fermentable carbohydrate intake, rumen content passage rate, and absorptive capacity of the rumen epithelium, affect the concentration of ruminal VFA (Penner et al., 2009). Whether the increased concentration of rumen VFA in this study was due to more extensive fermentation of OM producing more VFA, due to decreased absorption of VFA from the rumen, or a combination of both factors, is uncertain. A reduction in forage particle size may decrease the production of VFA because the particulate passage rate from the rumen is increased (Yang and Beauchemin, 2006). Despite this, several experiments reported that particle size had no effect on the outflow rate of rumen content (Beauchemin and Yang, 2005; Bhandari et al. 2008). Reducing the dietary forage particle length can also increase roughage digestibility and VFA production because of the increased surface area available for microbial attachment (Krause et al. 2002; Bhandari et al. 2007).
In contrast to previous reports, the present study showed that the ruminal cellulolytic bacteria $F$. succinogenes and $R$. flavefaciens were increased when the goats were fed the low-peNDF diet. Cellulolytic bacteria are sensitive to $\mathrm{pH}$, and low rumen $\mathrm{pH}$ (less than 5.80) possibly compromises their proliferation. Khafipour et al. (2009b) found that the F. succinogenes and $R$. flavefaciens decreased during the alfalfa pellet induced SARA $(510 \mathrm{~min} / \mathrm{d} \mathrm{pH}<5.6)$. However, graininduced mild SARA $(217 \mathrm{~min} / \mathrm{d} \mathrm{pH}<5.6)$ increased the populations of $R$. albus and $R$. flavefaciens. In the current study, the increased ruminal $F$. succinogenes and $R$. flavefaciens proportions indicated that more substrates or particulate surface (as mentioned previously) were available for these bacteria attachment and proliferation when goats were fed the low-peNDF diet compared with the control group.

Several studies have found that insufficient dietary peNDF (Khafipour et al., 2009a) and excessive dietaryfermentable carbohydrate (Mohammed et al., 2010; Aguerre et al., 2011) can cause MFD in dairy cows. In the current study, however, dietary peNDF did not affect milk fat content. This result is consistent with previous studies (Krause et al., 2002; Beauchemin et al., 2003; Yang and Beauchemin 2006). Dietary NDF $(34.7 \%)$ and NDF from forage $(27.4 \%)$ in the present study were above the minimum NRC (2001) recommendations for dairy cows. Zebeli et al. (2008) suggested that dietary peNDF ${ }_{1.18}$ ranging from 30 to $33 \%$ may be considered optimal to minimize the risk of SARA in high-producing dairy cows, and this range is higher than the peNDF ${ }_{1.18}$ level in the current study. Several studies have also indicated that goats can tolerate lower effective fiber or higher concentrate diet without causing SARA compared with cows. Zhao et al. (2011) found that dietary peNDF 1.18 above $20 \%$ can prevent of SARA in goats. Mele et al. (2008) further observed that low forage-to-concentrate ratio (67:37 vs. $35: 65,43.1$ vs. $37.7 \% \mathrm{NDF}$ ) did not affect milk yield and fat content of dairy goats. Desnoyers et al. (2008) also suggested that although high-concentrate diets reduced ruminal $\mathrm{pH}$, goats might adapt their feeding behavior by an increase eating and ruminating frequency to maintain ruminal $\mathrm{pH}$ in the normal range. Thus, diets employed in the current study might have contained adequate fiber to maintain milk fat concentration. However, because goats and cows differ in DMI, BW, and feeding behavior (Baumont et al., 2006), the peNDF requirement for dairy cows may not apply to dairy goats.

The MFD in dairy cows is commonly caused by inhibiting the synthesis of milk fat in the mammary glands by trans FA, which are produced as intermediates of the biohydrogenation of linoleic and linolenic acids to stearic acid (Shingfield et al., 2010). Shingfield 
et al. (2009) suggested that trans-10 C18:1 may elicit antilipogenic effects and likely contribute to MFD in dairy cows. Although the low-peNDF diet increased the proportion of milk trans-10 C18:1 in the current study, milk fat was not reduced. Shingfield et al. (2010) indicated that the MFD does not usually occur in small ruminants, even when goats or sheep are fed with highstarch diets containing plant or fish oil. Compared with cows, the mammary cells of goats are also less sensitive to the antilipogenic activity of trans FA intermediates (Shingfield et al., 2010). This may also explain the lack of change in milk fat content observed in response to different peNDF diets in dairy goats. In the present study, trans-10,cis-12 C18:2 were not detected in milk fat; this finding is consistent with the results of Serment et al. (2011).

In the current study, MEE was higher in goats fed with the low-peNDF diet. Zebeli et al. (2008) suggested that MEE increased as the ratio of dietary peNDF 1.18 content increased from 21.6 to $31.9 \%$ in dairy cows. Studies have also found that feed nutrients digestibilities are linearly increased by reducing the ration peNDF levels (Kononoff and Heinrichs, 2003; Yang and Beauchemin, 2006; Zhao et al., 2011). These results may explain the high MEE when goats were fed the low-peNDF diet.

Rumen bacteria are rich in OBCFA; however, the OBCFA profile differs across bacterial species (Fievez et al., 2012). Cellulolytic bacteria contain higher proportions of even-chain iso FA and iso C17:0 than amylolytic bacteria (Fievez et al., 2012; French et al., 2012). Most milk branched-chain FA originate from rumen bacteria, and the profile of these FA in milk can be used to assess the population of rumen bacteria, fermentation pattern, and SARA (Vlaeminck et al., 2006b; Fievez et al., 2012; Patel et al., 2013). In the current study, reducing dietary peNDF decreased milk fat iso C14:0 and iso C15:0 and increased the content of iso C17:0. These results agree with those of Alzahal et al. (2010), who found that SARA induced by decreasing the ratio of forage to concentrate from 74 to $56 \%$ also resulted in decreased iso C14:0 (0.127 to $0.071 \mathrm{~g} / 100 \mathrm{~g}$ of FA) and iso C15:0 (0.187 to $0.144 \mathrm{~g} / 100 \mathrm{~g}$ of FA) in milk, and in increased iso C17:0 (0.277 to $0.329 \mathrm{~g} / 100$ $\mathrm{g}$ of FA). However, Vlaeminck et al. (2006b) found that iso C17:0 in rumen liquid- and solid-associated bacteria decreases linearly as dietary forage content decreased. In the present study, the increase in cellulolytic bacteria in the rumen may result in depositing additional iso C17:0 into milk fat when goats received the lowpeNDF diet. These results indicated that the content of branched-chain FA (e.g., iso C17:0) in milk can be used to indicate changes in rumen bacterial populations.
The milk C17:0 is derived from the de novo synthesis of propionyl-CoA in the mammary gland and from the absorbed FA of rumen bacteria in the intestine (both originate from rumen propionate), and C17:1 is produced from $\mathrm{C} 17: 0$ by $\Delta^{9}$-desaturase in the mammary gland (Vlaeminck et al., 2006a; Fievez et al., 2012). Because rumen propionate production is positively correlated with dietary starch content (Bannink et al., 2006), Fievez et al. (2012) suggested that the increase in C17:0 and C17:1 in milk fat could be used as indicators of high concentrate-induced SARA. In the present study, therefore, the similar proportions of C17:0 and C17:1 in milk between treatments were attributed to the similar ruminal propionate production.

The reduced dietary peNDF increased the proportion of trans-10 C18:1 and decreased the proportion of trans-11 C18:1 in milk fat in the current study. Colman et al. (2013) observed that the proportion of milk trans-10 C18:1 increased from 1.03 to $6.38(\mathrm{~g} / 100$ $\mathrm{g}$ of FA) and trans-11 C18:1 decreased from 4.56 to $2.29(\mathrm{~g} / 100 \mathrm{~g}$ of FA) as dietary alfalfa pellet gradually increased (instead of alfalfa hay, 0 to $40 \%$ of DM). Several studies have indicated a shift from trans-11 C18:1 to trans-10 C18:1 of biohydrogenation when cows received high-concentrate diets (Roy et al., 2006; Pottier et al., 2006). This phenomenon is likely associated with the amount of ruminal Butyrivibrio fibrisolvens, which decreased when rumen $\mathrm{pH}$ is low and diets contain high PUFA (Khafipour et al., 2009b; Colman et al., 2013). However, the bacteria that participate in biohydrogenation process in rumen were not determined in the current experiment and need further study.

\section{CONCLUSIONS}

Chewing activity was decreased by reducing particle size of alfalfa hay. However, decreased chewing activity did not affect the mean ruminal $\mathrm{pH}$ or increase the incidence of SARA. Although the duration of ruminal $\mathrm{pH}$ below 5.6 and 5.8 was increased by decreasing dietary peNDF, milk fat was not decreased and the abundance of cellulolytic bacteria increased. The milk FA trans-10 C18:1, trans-11 C18:1, and OBCFA were changed by dietary peNDF. These results indicate that milk FA profile could be used to reflect the shift of cellulolytic bacteria in response to different dietary peNDF levels. In conclusion, the results of the current study show that a reduction in particle size of alfalfa hay in diets containing corn-based concentrate increased VFA concentration and milk energy efficiency without affecting milk composition in dairy goats. However, this effect should be further investigated under ad libitum conditions. 


\section{ACKNOWLEDGMENTS}

The research was supported by the National Key Technologies R\&D Program of China (Beijing, China; 2012BAD12B02, 2012BAD39B05) and the Program of International S\&T Cooperation of China (Beijing, China; 2010DFB34230).

\section{REFERENCES}

Aguerre, M. J., M. A. Wattiaux, J. M. Powell, G. A. Broderick, and C. Arndt. 2011. Effect of forage-to-concentrate ratio in dairy cow diets on emission of methane, carbon dioxide, and ammonia, lactation performance, and manure excretion. J. Dairy Sci. 94:30813093.

Allen, M. S. 2000. Effects of diet on short-term regulation of feed intake by lactating dairy cattle. J. Dairy Sci. 83:1598-1624.

Alzahal, O., M. M. Or-Rashid, S. L. Greenwood, and B. W. McBride. 2010. Effect of subacute ruminal acidosis on milk fat concentration, yield and fatty acid profile of dairy cows receiving soybean oil. J. Dairy Res. 77:376-384.

AOAC. 1990. Official Methods of Analysis. 15th ed. Assoc. Off. Anal. Chem., Arlington, VA.

Bannink, A., J. Kogut, J. Dijkstra, J. France, E. Kebreab, A. M. Van Vuuren, and S. Tamminga. 2006. Estimation of the stoichiometry of volatile fatty acid production in the rumen of lactating cows. J. Theor. Biol. 238:36-51.

Baumont, R., M. Doreau, S. Ingrand, I. Veissier, and V. Bels. 2006. Feeding in domestic vertebrates: From structure to behaviour. Pages 241-262 in Feeding and Mastication Behaviour in Ruminants. V. Bels, ed. CABI Publishing, Wallingford, UK.

Beauchemin, K. A., and W. Z. Yang. 2005. Effects of physically effective fiber on intake, chewing activity, and ruminal acidosis for dairy cows fed diets based on corn silage. J. Dairy Sci. 88:2117-2129.

Beauchemin, K. A., W. Z. Yang, and L. M. Rode. 2003. Effects of particle size of alfalfa-based dairy cow diets on chewing activity, ruminal fermentation, and milk production. J. Dairy Sci. 86:630-643.

Bhandari, S. K., S. Li, K. H. Ominski, K. M. Wittenberg, and J. C. Plaizier. 2008. Effects of the chop lengths of alfalfa silage and oat silage on feed intake, milk production, feeding behavior, and rumen fermentation of dairy cows. J. Dairy Sci. 91:1942-1958.

Bhandari, S. K., K. H. Ominski, K. M. Wittenberg, and J. C. Plaizier. 2007. Effects of chop length of alfalfa and corn silage on milk production and rumen fermentation of dairy cows. J. Dairy Sci. 90:2355-2366.

Colman, E., E. Khafipour, B. Vlaeminck, B. De Baets, J. C. Plaizier, and V. Fievez. 2013. Grain-based versus alfalfa-based subacute ruminal acidosis induction experiments: Similarities and differences between changes in milk fatty acids. J. Dairy Sci. 96:4100-4111.

Denman, S. E., and C. S. McSweeney. 2005. PCR-based methods for analysis of populations and gene expression. 3.2 Quantitative (real time) PCR. Pages 105-115 in Methods in Gut Microbial Ecology for Ruminants. H. Makkar and C. S. McSweeney, ed. Springer, Houten, the Netherlands.

Desnoyers, M., C. Duvaux-Ponter, K. Rigalma, S. Roussel, O. Martin, and S. Giger-Reverdin. 2008. Effect of concentrate percentage on ruminal $\mathrm{pH}$ and time-budget in dairy goats. Animal 2:1802-1808.

Fievez, V., E. Colman, J. M. Castro-Montoya, I. Stefanov, and B. Vlaeminck. 2012. Milk odd- and branched-chain fatty acids as biomarkers of rumen function-An update. Anim. Feed Sci. Technol. 172:51-65.

French, E. A., S. J. Bertics, and L. E. Armentano. 2012. Rumen and milk odd- and branched-chain fatty acid proportions are minimally influenced by ruminal volatile fatty acid infusions. J. Dairy Sci. 95:2015-2026.

Gozho, G. N., J. C. Plaizier, D. O. Krause, A. D. Kennedy, and K. M. Wittenberg. 2005. Subacute ruminal acidosis induces ruminal lipopolysaccharide endotoxin release and triggers an inflammatory response. J. Dairy Sci. 88:1399-1403.
ISO-IDF. 2002. Milk Fat-Preparation of Fatty Acid Methyl Esters. International Organization for Standardization, International Dairy Federation, Brussels, Belgium.

Khafipour, E., D. O. Krause, and J. C. Plaizier. 2009a. Alfalfa pelletinduced subacute ruminal acidosis in dairy cows increases bacterial endotoxin in the rumen without causing inflammation. J. Dairy Sci. 92:1712-1724.

Khafipour, E., S. Li, J. C. Plaizier, and D. O. Krause. 2009b. Rumen microbiome composition determined using two nutritional models of subacute ruminal acidosis. Appl. Environ. Microbiol. 75:7115-7124.

Kononoff, P. J., and A. J. Heinrichs. 2003. The effect of reducing alfalfa haylage particle size on cows in early lactation. J. Dairy Sci. $86: 1445-1457$

Kononoff, P. J., A. J. Heinrichs, and H. A. Lehman. 2003. The effect of corn silage particle size on eating behavior, chewing activities, and rumen fermentation in lactating dairy cows. J. Dairy Sci. $86: 3343-3353$.

Krause, K. M., and D. K. Combs. 2003. Effects of forage particle size, forage source, and grain fermentability on performance and ruminal pH in midlactation cows. J. Dairy Sci. 86:1382-1397.

Krause, K. M., D. K. Combs, and K. A. Beauchemin. 2002. Effects of forage particle size and grain fermentability in midlactation cows. I. Milk production and diet digestibility. J. Dairy Sci. 85:19361946.

Krause, K. M., and G. R. Oetzel. 2006. Understanding and preventing subacute ruminal acidosis in dairy herds: A review. Anim. Feed Sci. Technol. 126:215-236.

Lammers, B. P., D. R. Buckmaster, and A. J. Heinrichs. 1996. A simple method for the analysis of particle sizes of forage and total mixed rations. J. Dairy Sci. 79:922-928.

Luna, P., M. Juárez, and M. A. de la Fuente. 2005. Validation of a rapid milk fat separation method to determine the fatty acid profile by gas chromatography. J. Dairy Sci. 88:3377-3381.

McSweeney, C. S., and S. E. Denman. 2007. Effect of sulfur supplements on cellulolytic rumen micro-organisms and microbial protein synthesis in cattle fed a high fibre diet. J. Appl. Microbiol. 103:1757-1765.

Mele, M., A. Serra, A. Buccioni, G. Conte, A. Pollicardo, and P. Secchiari. 2008. Effect of soybean oil supplementation on milk fatty acid composition from Saanen goats fed diets with different forage:concentrate ratios. Ital. J. Anim. Sci. 7:297-311.

Mertens, D. R. 1997. Creating a system for meeting the fiber requirements of dairy cows. J. Dairy Sci. 80:1463-1481.

Mohammed, R., J. J. Kennelly, J. K. G. Kramer, K. A. Beauchemin, C. S. Stanton, and J. J. Murphy. 2010. Effect of grain type and processing method on rumen fermentation and milk rumenic acid production. Animal 4:1425-1444.

NRC. 2001. Nutrient Requirements of Dairy Cattle. 7th rev. ed. Natl. Acad. Sci., Washington, DC.

Patel, M., E. Wredle, and J. Bertilsson. 2013. Effect of dietary proportion of grass silage on milk fat with emphasis on odd- and branched-chain fatty acids in dairy cows. J. Dairy Sci. 96:390-397.

Penner, G. B., J. R. Aschenbach, G. Gabel, R. Rackwitz, and M. Oba. 2009. Epithelial capacity for apical uptake of short chain fatty acids is a key determinant for intraruminal $\mathrm{pH}$ and the susceptibility to subacute ruminal acidosis in sheep. J. Nutr. 139:1714-1720.

Plaizier, J. C., D. O. Krause, G. N. Gozho, and B. W. McBride. 2008. Subacute ruminal acidosis in dairy cows: The physiological causes, incidence and consequences. Vet. J. 176:21-31.

Pottier, J., M. Focant, C. Debier, G. De Buysser, C. Goffe, E. Mignolet, E. Froidmont, and Y. Larondelle. 2006. Effect of dietary vitamin $\mathrm{E}$ on rumen biohydrogenation pathways and milk fat depression in dairy cows fed high-fat diets. J. Dairy Sci. 89:685-692.

Roy, A., A. Ferlay, K. J. Shingfield, and Y. Chilliard. 2006. Examination of the persistency of milk fatty acid composition responses to plant oils in cows given different basal diets, with particular emphasis on trans-C18:1 fatty acids and isomers of conjugated linoleic acid. Anim. Sci. 82:479-492.

SAS Institute. 2003. SAS User's Guide. Statistics. Version 8 ed. SAS Inst. Inc., Cary, NC. 
Serment, A., P. Schmidely, S. Giger-Reverdin, P. Chapoutot, and D. Sauvant. 2011. Effects of the percentage of concentrate on rumen fermentation, nutrient digestibility, plasma metabolites, and milk composition in mid-lactation goats. J. Dairy Sci. 94:3960-3972.

Shingfield, K. J., L. Bernard, C. Leroux, and Y. Chilliard. 2010. Role of trans fatty acids in the nutritional regulation of mammary lipogenesis in ruminants. Animal 4:1140-1166.

Shingfield, K. J., A. Sæbø, P. C. Sæbø, V. Toivonen, and J. M. Griinari. 2009. Effect of abomasal infusions of a mixture of octadecenoic acids on milk fat synthesis in lactating cows. J. Dairy Sci. 92:4317-4329

Stevenson, D. M., and P. J. Weimer. 2007. Dominance of Prevotella and low abundance of classical ruminal bacterial species in the bovine rumen revealed by relative quantification real-time PCR. Appl. Microbiol. Biotechnol. 75:165-174.

Teimouri Yansari, A., R. Valizadeh, A. Naserian, D. A. Christensen, P. Yu, and F. Eftekhari Shahroodi. 2004. Effects of alfalfa particle size and specific gravity on chewing activity, digestibility, and performance of Holstein dairy cows. J. Dairy Sci. 87:3912-3924.

Van Soest, P. J., J. B. Robertson, and B. A. Lewis. 1991. Methods for dietary fiber, neutral detergent fiber and nonstarch polysaccharide in relation to animal nutrition. J. Dairy Sci. 74:3583-3597.

Vlaeminck, B., C. Dufour, A. Van Vuuren, A. Cabrita, R. J. Dewhurst, D. Demeyer, and V. Fievez. 2005. Use of odd and branched-chain fatty acids in rumen contents and milk as a potential microbial marker. J. Dairy Sci. 88:1031-1042.

Vlaeminck, B., V. Fievez, A. R. J. Cabrita, A. J. M. Fonseca, and R. J. Dewhurst. 2006a. Factors affecting odd- and branched-chain fatty acids in milk: A review. Anim. Feed Sci. Technol. 131:389-417.

Vlaeminck, B., V. Fievez, D. Demeyer, and R. J. Dewhurst. 2006b. Effect of forage:concentrate ratio on fatty acid composition of rumen bacteria isolated from ruminal and duodenal digesta. J. Dairy Sci. 89:2668-2678

Wang, R. F., W. W. Cao, and C. E. Cerniglia. 1997. PCR detection of Ruminococcus spp. in human and animal faecal samples. Mol. Cell. Probes 11:259-265.

Wheelock, J. B., R. P. Rhoads, M. J. VanBaale, S. R. Sanders, and L. H. Baumgard. 2010. Effects of heat stress on energetic metabolism in lactating Holstein cows. J. Dairy Sci. 93:644-655.

Yang, W. Z., and K. A. Beauchemin. 2006. Increasing the physically effective fiber content of dairy cow diets may lower efficiency of feed use. J. Dairy Sci. 89:2694-2704

Yang, W. Z., and K. A. Beauchemin. 2007. Altering physically effective fiber intake through forage proportion and particle length: Digestion and milk production. J. Dairy Sci. 90:3410-3421.

Zebeli, Q., J. R. Aschenbach, M. Tafaj, J. Boguhn, B. N. Ametaj, and W. Drochner. 2012. Invited review: Role of physically effective fiber and estimation of dietary fiber adequacy in high-producing dairy cattle. J. Dairy Sci. 95:1041-1056.

Zebeli, Q., J. Dijkstra, M. Tafaj, H. Steingass, B. N. Ametaj, and W. Drochner. 2008. Modeling the adequacy of dietary fiber in dairy cows based on the responses of ruminal $\mathrm{pH}$ and milk fat production to composition of the diet. J. Dairy Sci. 91:2046-2066.

Zebeli, Q., D. Mansmann, H. Steingass, and B. N. Ametaj. 2010. Balancing diets for physically effective fibre and ruminally degradable starch: A key to lower the risk of sub-acute rumen acidosis and improve productivity of dairy cattle. Livest. Sci. 127:1-10.

Zhao, X. H., T. Zhang, M. Xu, and J. H. Yao. 2011. Effects of physically effective fiber on chewing activity, ruminal fermentation, and digestibility in goats. J. Anim. Sci. 89:501-509. 